\title{
Reptilian Glycan
}

National Cancer Institute

\section{Source}

National Cancer Institute. Reptilian Glycan. NCI Thesaurus. Code C158048.

An oligosaccharide protein modification that is synthesized by reptilian cells. 